\title{
Organizational Citizenship Behavior Factor Structure among Employees in Hotel Industry
}

\author{
Shaiful Annuar Khalid (Corresponding author) \\ Faculty of Business Management, Universiti Teknologi Mara (UiTM) \\ 02600, Arau, Perlis, Malaysia \\ Tel: 60-12-5140-436Ｅ-mail:shaiful@perlis.uitm.edu.my
}

Hassan Ali

Faculty of Business Management, Universiti Utara Malaysia

06010 Sintok, Kedah, Malaysia

Tel: 60-19-4541162Ｅ-mail: hassan@uum.edu.my

Mohammad Ismail

Faculty of Business Management, Universiti Teknologi Mara (UiTM)

02600, Arau, Perlis, Malaysia

Tel: 60-4-9861-001 E-mail: mohammadismail@perlis.uitm.edu.my

Norshimah Abdul Rahman

Faculty of Business Management, Universiti Teknologi Mara (UiTM)

02600, Arau, Perlis, Malaysia

Tel: 604-9861-001Ｅ-mail: shima70@perlis.uitm.edu.my

Kamsol Mohamed Kassim

Faculty of Business Management, Universiti Teknologi Mara (UiTM)

02600, Arau, Perlis, Malaysia

Tel: 60-19-5505-432 E-mail: Kamsol@perlis.uitm.edu.my

Rozihana Shekh Zain

Faculty of Business Management, Universiti Teknologi Mara (UiTM)

02600, Arau, Perlis, Malaysia

Tel: 60-4-9861-001Ｅ-mail: rozihana@perlis.uitm.edu.my

\begin{abstract}
Most of the literature on organizational citizenship behavior (OCB) was developed in the West, mainly North America. Not much is known about the meaningfulness and categories of OCB in other cultural environment such as Malaysia. This study investigates the dimensionality of OCB using a sample of hotel employees. Factors analysis of OCB items as rated by superiors revealed 5 dimensions, labeled as helping behavior, sportsmanship, conscientiousness, patience and civic virtue. Factor analysis of OCB items based on self- ratings (non manager employees) resulted in six dimensions, named as altruism, courtesy, conscientiousness, sportsmanship, effort expended and civic virtue. These results show that the forms of OCB seem to hold relatively well in another international context, although there are some differences.
\end{abstract}


Keywords: Organizational citizenship behavior, Factor analysis, Hotel industry

\section{Introduction}

According to Organ (1988), organizational citizenship behavior (OCB) refers to a universal set of behaviors exhibited by employees that are supportive, discretionary, and go beyond normal job requirements. The word discretionary, according to Organ (1988) means that the behavior is not a requirement of formal job description. OCB is a matter of individual choice and failure to exhibit such behavior is not generally considered as cause for penalty. What is important is that these examples describe behaviors which are helpful to the organization, yet they are not behaviors considered part of the core elements of the job. Over the years, the topic of organizational citizenship behavior (OCB) has generated a substantial amount of scholarly attention (for a review, see Podsakoff, MacKenzie, Paine \& Bachrach, 2000) because these behaviors contribute to effective functioning of the organization (Podsakoff, Ahearne \& MacKenzie, 1997; Podsakoff \& MacKenzie, 1994). It has been studied in a diversity of disciplines such as marketing, human resources management, health care and economics (Lievens \& Anseel, 2004). Several measures and OCB domains have been developed such as altruism, conscientiousness, loyalty, civic virtue, voice, functional participation, sportsmanship, courtesy and advocacy participation (see, for example, Bateman \& Organ, 1983; William \& Anderson, 1991; VanDyne, Graham \& Dienesch, 1994). However, there are five categories of OCB that are frequently recognized in research (LePine, Erev \& Johnson, 2002) which are altruism (e.g. helps others who have heavy work loads), conscientiousness (e.g. is always punctual at work), sportsmanship (e.g. tends to make a "mountain out of molehills"), courtesy (e.g. informs you before taking any important actions), and civic virtue (e.g. attends functions that are not required, but help the organization image).

In term of $\mathrm{OCB}$ ratings, the majority of $\mathrm{OCB}$ research have utilized superior-ratings with justification that self-ratings of OCB are exposed to self serving bias, that is individuals tend to present themselves in a way that makes them emerge positive (Schnake, 1991). However, the use of self-ratings is not rare in OCB research. A growing number of research have utilized self-ratings of OCB such as Carmeli and Freund (2002) and Kuehn and Al-Busaidi (2002). Even though the use of superior-ratings alone mitigates concern regarding the problem of common method variance, a great deal of citizenship behavior may escape the attention of the superior (Organ \& Konovsky, 1989). This suggests that measuring employee citizenship behavior from more than one source may supply a richer perspective on employee OCB. This is also consistent with suggestions by Allen, Barnard, Rush and Russell (2000) that the overall level of OCB is likely best captured by rating from multiple sources. In line with this suggestion, we used two different sources of rating (the self-ratings and superior-ratings of $\mathrm{OCB}$ ).

Since most OCB studies have been conducted in the North America (Farh, Early \& Lin, 1997), OCB measurement has received comparatively limited attention in other contexts (Paille, 2009). Research on OCB measurement in other cultural context is important since Podsakoff et al., (2000) argue that "cultural context may affect the forms of citizenship behavior observed in organization (e.g., the factor structure) (p. 556). Therefore the present study aims to contribute to the growing number of studies on OCB by investigating the content domain or dimensions of OCB in a sample of hotel employees. Employees in the hotel industry were selected as the study context because offering a high level of quality services and increasing operational efficiency involves extra-role behaviors such as OCB (Getty \& Getty, 2003).

\section{Method}

\subsection{Procedure}

Data collection began by sending a cover letter that explained the study and invitation for participation to all 76 star-ratings hotels in the northern region of Peninsular Malaysia. Of the 76 star-ratings hotels contacted, 68 hotels responded and agreed to take part. Two sets of questionnaires were used to tap the level of employees OCB, which are superior questionnaire (for superior-ratings) and subordinate questionnaire (for self-ratings). There were 834 pairs of subordinate and superior questionnaires distributed to 68 star-ratings hotels. In each hotel, employees were selected using systematic sampling. Questionnaires were distributed to superiors (managers or heads of department) and subordinates through hotels human resources managers. Each superior was given two sets of questionnaires. The first set asked them to evaluate their subordinates levels of OCB (the number of questionnaires depend on the number of subordinates to be evaluated). The superiors were also asked to distribute questionnaires to their subordinates for self-ratings of OCB. Participants were told that anonymity and confidentiality were assured.

\subsection{Research Instruments}

A 20 items scale developed by Podsakoff and Mackenzie(as cited in Niehoff \& Moorman, 1993), together with 22 newly developed items were used to measure the five OCB domains that are altruism, courtesy, sportsmanship, conscientiousness, and civic virtue. Respondents were asked to indicate the extent of OCB demonstration using a 5-point Likert scale format from (1) strongly disagree to (5) strongly agree. Study by Moorman (1991) supported the psychometric properties of this scale. Regarding the newly developed items, initially 26 new items were generated 
based on Organ (1988) conceptualization of OCB and presented to several hotel human resource officers as well as hotel superiors to make sure that the items capture those behaviors that are not part of employee's formal job description but are considered important for hotels organizational functioning. After discussions, 4 items are deleted because from the view points of hotel superiors and human resource superiors, those items are not applicable across job levels and not considered as extra role. Minor modification is made to the questionnaire to suit the study sample. The word "organization" was replaced by the word "hotels". For the self-ratings of OCB, the word "I" was added to each item. For the superior's questionnaire, every statement started with the words "This employee...."

\section{Results and discussions}

In total, 557 employees working in some 63 hotels from the northern region of Peninsular Malaysia provided self-ratings of OCB. The sample covered a broad range of hotel non manager occupations. Superior-ratings of OCB for the 557 subordinates were obtained from 287 superiors or head of departments. In the present study, superiors rated between one to five employees each but the majority rated only two employees. This ratio is better than some of the previous studies whereby a superior rated up to 10 employees (e.g., Cappelli \& Rogovsky, 1998) or 45 employees (e.g., Niehoff \& Moorman, 1993). According to Van Scooter and Motowidlo (1996), bias can be eliminated by reducing the number of subordinates to be rated by superiors. Fifty-five percent of the respondents indicated that they were male and $45 \%$ identified themselves as female. In term of ethnicity, $77 \%$ indicated they were Malay, $13 \%$ Chinese, $8 \%$ Indian and $2 \%$ others. Respondents ranged in age from 18 to 56 years with a mean of 29 years. The averaged employees had been with the hotels for 4 years. In term of marital status, $50 \%$ of the respondents were married, $48 \%$ were single, $2 \%$ were widowed and the remaining $1 \%$ was others.

Two separate principal component analysis (each for superior-ratings and self-ratings), with a varimax rotation, were performed on the items indicating the extent to which employees displayed the 42 citizenship behaviors and to test for structural similarity between the two ratings. There is a widespread use of principal component analysis which is suitable if the number of variables exceeds 30 . Furthermore, varimax rotation seems to give a clearer separation of factors (Hair, Anderson, Tatham \& Black, 1998). Research investigating the OCB factor structure based on existing and established scales has also adopted an exploratory factor analysis, using principal component method (e.g., Turnipseed \& Murkison, 2000; Organ \& Lingl, 1995; Morrison, 1994; Coyle-Shapiro \& Kessler, 2000; Latham \& Skarlicki, 1995). Our analysis was based on a subject: item ratio of 13:1 which is higher than recommended (Hair et al., 1998). In both factor analyses, items loadings greater than .50 were used to determine the factor structure. This value is consistent with proper statistical practice in which factor loadings greater than .50 are considered very significant (Hair et al., 1998). Initially, factor loading of less than .50 (e.g., .30 and .40) were attempted, but the factors derived were not clearly defined and uninterpretable. An item was assigned to a factor only if a differential of .20 or more existed between two highest values among the components.

For superior rating of OCB, a series of factor analysis were conducted on the initial 42 items to determine which items grouped to form dimensions. Twelve items were deleted because of low communalities that are below .50. These analyses resulted in a five-factor solution with 3 to 14 items loading on each factor. The scree plot and differences among eigenvalues supported a five factor solution for superior-ratings of OCB. The Kaiser-Meyer-Olkin measure of sampling adequacy was .952, which indicated that the data were suitable for factor analysis. The result of this analysis is outlined in Table 1. The OCB scales by Podsakoff and MacKenzie (as cited in Niehoff \& Moorman, 1993), has been suggested to consist of 5 factors measuring altruism, courtesy, sportsmanship, civic virtue and conscientiousness. The present study found general support for this five factor model except the lack of courtesy and altruism factors. As illustrated in Table 1, 14 items loaded in the first factor (7 altruism items, 6 courtesy items and 1 civic virtue item). It is worth noting that, previous research has indicated that superiors may not be able to recognize some of the finer distinctions between altruism and courtesy and tending to lump these into one broad helping construct (Podsakoff \& MacKenzie, 1994). Accordingly, in the present study, the first factor was labelled helping behavior. Nine items loaded on factor 2 and factor 4 and the majority of these items were the sportsmanship items. Of the 6 items loaded on factor 2 , 4 of these items were sportsmanship items together with 1 courtesy item and 1 conscientiousness item. The four sportsmanship items loaded on factor 2 were those items adapted from Podsakoff and Mackenzie (as cited in Niehoff \& Moorman, 1993). For reason of consistency with the previous research, the label of sportsmanship is used for factor 2. The 3 self-developed items initially tended to measure sportsmanship loaded on factor 4 . It was felt that these 3 items reflect the employees' ability to persevere with something inconvenience or hardship at the work place. This factor was labelled patience. Four conscientiousness items loaded on factor 3 and three civic virtue items loaded on factor 5 . The five factors explained $63.14 \%$ of the variance in the data with extracted factors eigenvalue of more than 1.

A summary of the factor statistics in shown in Table 2. The Cronbach alpha for the superior-ratings of OCB dimensions are: .94 (Helping behavior), .88 (Sportsmanship), .82 (conscientiousness), .76 (patience) and .81 (civic virtue). Helping behavior, conscientiousness, sportsmanship and civic virtue are considered as common dimensions as they resemble those OCB dimensions found in the West. Patience is considered as an extended dimension whose content domain 
differs from existing Western OCB dimension. Whilst the results have important implications for the validity of the superior-ratings of OCB construct, the sample used in this study is different from the OCB samples investigated by previous studies. As such, it would be unwise to assume that exactly the same results of factors would occur in a sample of hotel employees. Moreover, in this study, half of the OCB construct contained new items. It is worth noting that, Payne (1970), indicated that different sample of respondents may result in different factor loading.

\section{$<<$ INSERT TABLE $1>>$}

\section{$<<$ INSERT TABLE $2>>$}

As illustrated in Table 3, for self-ratings of OCB, slightly different results were obtained, whereby the factor analysis revealed six factors. The Kaiser-Meyer-Olkin measure of sampling adequacy was .904 , which indicated that the data were suitable for factor analysis. The first factor consisted of 7 items ( 5 courtesy items, 1 conscientiousness item and 1 civic virtue item). This factor was labelled courtesy. Four altruism items loaded were on factor 2. Seven conscientiousness items were loaded separately on two factors, which is 4 items on factor 3 and 3 items on factor 4 . The 4 self-developed items initially tended to measure conscientiousness were loaded on factor 3 . Since these 4 items focused on the employees willingness and ability to expend effort by being present at the work place and also actively contributing to organization through ideas and efforts, factor 3 was labelled as effort expended. The three conscientiousness items loaded on factor 4, were those adapted items, and were labelled conscientiousness. Three civic virtue items were loaded on factor 5 and 3 sportsmanship items were loaded on factor 6 . The Cronbach-alpha for the self-ratings of OCB dimensions are: .87 (courtesy), .80 (altruism), .67 (effort expended), .78 (conscientiousness), .70 (civic virtue) and .71 (sportsmanship). The six factors explained $61.87 \%$ of the variance in the data. A summary of the factor statistics is shown in Table 4.

\section{$<<$ INSERT TABLE $3>>$ \\ $<<$ INSERT TABLE $4>>$}

The emergence of two new facets of OCB especially patience is probably unique in the Malaysian context as it was never measured in the Western literature. Since examination of OCB outside of the context of the US is limited (see, for example, Farh et al., 1997; Turnipseed \& Murkison, 2000), this study provides initial empirical support for the existence of both universal and extended aspects of OCB in a non Western context. From the theoretical perspective, the extended dimension of patience seems to be one of the elements among Asian cultures (Markus, 2002). Liu and Fellows (2008) and Felfe, Yan and Six (2008) state that collectivistic was found to be related to OCB and individualistic persons are less likely to exhibit OCB. Additionally, on the basis of equity theory, it could be possible that patience and effort expended were exhibited by hotel employees in return for a fair pay and benefits from the management (Moorman, 1991).

\section{Conclusion}

The initial objective of this study was to develop OCB factor structure for the non managers of hotel employees in Malaysia. Additionally, consistent with the suggestion by Lievens and Anseel (2004), this study also examined the equivalence of OCB scales across superior and self-ratings of the same target person. Generally our results corroborate previous studies in the US and in other international context. The general picture is that the forms of citizenship behavior observed in organizations hold relatively well across international contexts. Paille (2009) for example found support for a 4-factor model (altruism, civic virtue, sportsmanship, helping others) in the French-language context. However, some differences should also be noted. The results revealed that superiors and self-ratings yielded slightly different factors. While superior-ratings of OCB yielded a new dimension of patience, self-ratings of OCB provided a new dimension of effort expended. Interestingly, these new dimensions were formed based on newly developed items. It is common that different ratings will give slightly different results. Morrison (1994) for example, stated that behavior such as OCB will be seen differently by employees and their superiors. Additionally, Nunnally (1967) indicated that the heterogeneity of the subjects in term of age, gender and culture may affect the factors generated. However, it is interesting to note, that using a different ratings will give a richer perspective of employee OCB. This study found that several facets of the OCB construct which had been measured in the Western literature were also evident in the Malaysian context. Employees were selected from several departments, positions and more than 60 hotels. Such as sample increases the external generalizability of the results. In term of practical implication, since some studies demonstrated that employees' citizenship behaviors contribute to organizational effectiveness, hotel managers should take necessary steps to encourage OCB among employees. For example, managers may exhibit citizenship behavior themselves in order to communicate to employees that such behaviors are valued by the management. In terms of the study limitations, our findings are limited to the items used to measure OCBs in this particular study. The use of other OCB measures may provide different factors. In terms of future research, it will be useful to investigate OCB factor structure among diverse samples of workers and industry. In this respect, Farh et al., (1997) have suggested the use of an iterative procedure of item generation and testing to develop an indigenous scale of OCB that yielded 
context-specific dimensions.

\section{References}

Allen, T.D., Barnard, S., Rush, M.C., \& Russell, J.E. A. (2000). Ratings of organizational citizenship behavior: Does the source make a difference? Human Resource Management Review, 10, 97-115.

Bateman, T.S., \& Organ, D.W. (1983). Job satisfaction and the good soldier: The relationship between affect and employee citizenship. Academy of Management Journal, 26, 587-595.

Cappelli, P., \& Rogovsky, N. (1998). Employee involvement and organizational citizenship: Implications for labor law reform and lean production. Industrial and Labour Relations Review, 51, 633-654.

Carmeli, A., \& Freund, A. (2002). The relationship between work and workplace attitudes and perceived external prestige. Corporate Review, 5, 51-68.

Coyle-Shapiro, J., \& Kessler, I. (2000). Consequences of the psychological contract for the employment relationship: A large scale survey. Journal of Management Studies, 37, 904-930.

Farh, J.L., Earley, P.C., \& Lin, S.C.(1997). Impetus for action: A cultural analysis of justice and organizational citizenship behavior in Chinese society. Administrative Science Quarterly, 42, 421-444.

Felfe, J., Yan, W., \& Six, B. (2008). The impact of individual collectivism on commitment and its influence on organizational citizenship behavior and turnover in three countries. International Journal of Cross Cultural Management, 8(2), 211-223.

Getty, J.M., \& Getty, R.L. (2003). Lodging quality index (LQI): Assessing customers' perception of quality delivery. International Journal of Contemporary Hospitality Management, 15, 94-104.

Hair, J.F. Jr., Anderson, R.E., Tatham, R.L., \& Black, W.C. (1998). Multivariate data analysis. (5th ed.). New Jersey: Prentice Hall.

Kuehn, K.W., \& Al-Busaidi, Y. (2002). Citizenship behavior in a non-western context: An examination of the role of satisfaction, commitment and job characteristics on self-reported organizational citizenship behavior. International Journal of Commerce \& Management, 12, 107-125.

Latham, G. P., \& D. P. Skarlicki. (1995). Criterion related validity of the situational and patterned behavior description interviews with organizational citizenship behavior. Human Performance, 8, 67-80.

LePine, J.A., Erez, A., \& Johnson, D.E. (2002). The nature and dimensionality of OCB: A critical review and meta-analysis. Journal of Applied Psychology,87,52-65.

Lievens, F., \& Anseel, F. (2004). Confirmatory factor analysis and invariance of an organizational citizenship behavior measure across samples in a Dutch-speaking context. Journal of Occupational and Organizational Psychology, 77, 299-306.

Liu, A. M. M., \& Fellows, R. (2008). Behavior of quantity surveyors as organizational citizens. Construction Management and Economics, 26(12), 1271-1279.

Markus, A. (2002). Information visualization for advanced vehicle displays. Information Visualization, 1, 95-101.

Moorman, R.H. (1991). Relationship between organizational justice and organizational citizenship behaviors: Do fairness perceptions influence employee citizenship? Journal of Applied Psychology, 76, 845-855.

Morrison, E.W. (1994). Role definitions and organizational citizenship behavior: The importance of the employee's perspective. Academy of Management Journal, 37, 1543-1567.

Niehoff, B.P., \& Moorman, R.H. (1993). Justice as a mediator of the relationship between methods of monitoring and organizational citizenship behavior. Academy of Management Journal, 36, 527-556.

Nunnally, J.C. (1967). Psychometric theory. New York: McGraw-Hill.

Organ, D.W. (1988). Organizational Citizenship Behavior:The good soldier syndrome. Lexington, MA:Lexington Books.

Organ, D.W., \& Konovsky, M. (1989). Cognitive versus affective determinants of organizational citizenship behavior. Journal of Applied Psychology, 74,157-164.

Organ, D.W., \& Lingl, A. (1995). Personality, satisfaction, and organizational citizenship behavior. Journal of Social Psychology, 135, 339-350.

Paille, P. (2009). Assessing organizational citizenship behavior in the French Context: Evidence for the Four-Dimension Model. The Journal of Psychology, 143(2), 133-147.

Payne, R. (1970). Factor analysis of a Maslow-type need satisfaction questionnaire. Personnel Psychology, 23, 251-268. 
Podsakoff, P.M., MacKenzie, S.B., Paine, J.B., \& Bachrach, D.G. (2000). Organizational citizenship behavior: A critical review of the theoretical and empirical literature and suggestions for future research. Journal of Management, 26,513-563.

Podsakoff, P.M., \& MacKenzie, S.B. (1994). Organizational citizenship behaviors and sales unit effectiveness. Journal of Marketing Research, 31, 351-364.

Podsakoff, P.M., Ahearne, M., \& MacKenzie, S.B. (1997). Organizational citizenship behavior and the quantity and quality of work group performance. Journal of Applied Psychology, 82, 262-270.

Schnake, M.E. (1991). Organizational citizenship: A review, proposed model, and research agenda. Human Relations, 44, 735-759.

Turnipseed, D., \& Murkison, E. (2000). A bi-cultural comparison of organizational citizenship behavior: Does the OCB phenomenon transcend national culture? The International Journal of Organizational Analysis, 8, $200-222$.

VanDyne, L., Graham, J.W., \& Dienesch, R.M. (1994). Organizational citizenship behavior: Construct redefinition, operationalization, and validation. Academy of Management Journal, 37, 765-802.

Van Scotter, J.R., \& Motowildo, S.J. (1996). Interpersonal facilitation and job dedication as separate facets of contextual performance. Journal of Applied Psychology, 81, 525-531.

Williams, L.J., \& Anderson, S.E. (1991). Job satisfaction and organizational commitment as predictors of organizational citizenship and in-role behaviors. Journal of Management, 17, 601-617. 
Table 1. Summary of factor analysis for superior ratings OCB items

\begin{tabular}{|c|c|c|c|c|c|}
\hline & \multicolumn{5}{|c|}{ Component } \\
\hline Organizational Citizenship Behavior Items & $\mathrm{F} 1$ & $\mathrm{~F} 2$ & F3 & F4 & F5 \\
\hline $\begin{array}{l}\text { 1. Consults you or other individuals who might be affected by his/her } \\
\text { actions or decisions. }\end{array}$ & .72 & .05 & .20 & .01 & .18 \\
\hline 2. Helps others who have heavy work loads & .69 & .17 & .09 & .33 & .06 \\
\hline $\begin{array}{l}\text { 3. Willingly gives his/her time to help others who have work-related } \\
\text { problems. }\end{array}$ & .68 & .18 & .07 & .30 & .13 \\
\hline 4. Informs you before taking any important actions. & .68 & .16 & .35 & -.02 & .06 \\
\hline 5. Takes steps to prevent problems with other workers. & .67 & .32 & .24 & .14 & .16 \\
\hline 6. Helps others who have been absent. & .66 & .14 & .11 & .33 & .08 \\
\hline 7. Is always willing to cooperate with others to get a job done. & .65 & .41 & .19 & .21 & .12 \\
\hline $\begin{array}{l}\text { 8. Is willing to share his/her knowledge and expertise to help others } \\
\text { improve their work performance. }\end{array}$ & .64 & .35 & .14 & .21 & .15 \\
\hline 9. Helps new people to get accustomed to work environment. & .63 & .24 & .16 & .31 & .25 \\
\hline 10. Help others with demanding work assignment. & .61 & .20 & .16 & .24 & .26 \\
\hline 11. Does not abuse the rights of others. & .61 & .28 & .27 & -.03 & .13 \\
\hline 12. Helps train new people even though it is not required. & .61 & .22 & .17 & .30 & .24 \\
\hline 13. Pay attention to hotel memos or announcements. & .57 & .23 & .32 & .05 & .30 \\
\hline 14. Concerned with the effects of his/her actions or decision on others. & .55 & .23 & .17 & .19 & .14 \\
\hline 15. Tends to make a "mountain out of molehills"(R) & .12 & .81 & .12 & .20 & .14 \\
\hline 16. Always finds faults with what the hotel is doing( $R$ ). & .19 & .76 & .15 & .17 & .13 \\
\hline $\begin{array}{l}\text { 17. Always focuses on what's wrong with his/her situation, rather than } \\
\text { with the positive } \\
\text { side of it }(\mathrm{R})\end{array}$ & .33 & .71 & .22 & -.01 & .09 \\
\hline 18. Consumes a lot of time complaining about trivial matters.(R ) & .33 & .67 & .21 & .14 & .05 \\
\hline 19. Is always neglectful in coordinating his/her work with others. ( $R$ ) & .35 & .66 & .07 & .10 & .07 \\
\hline 20. Puts in less effort than other members of his/her work group. (R ) & .11 & .65 & .09 & .33 & .20 \\
\hline 21. Never takes long lunches. & .17 & .15 & .84 & .19 & .12 \\
\hline 22. Does not take extra breaks. & .18 & .18 & .84 & .18 & .07 \\
\hline 23. Is always punctual at work. & .38 & .16 & .59 & .04 & .06 \\
\hline 24. Always maintain a tidy work area. & .39 & .17 & .55 & .09 & .09 \\
\hline $\begin{array}{l}25 \text {. Is the kind of person who can tolerate occasional inconvenience at } \\
\text { work. }\end{array}$ & .29 & .22 & .09 & .73 & .13 \\
\hline $\begin{array}{l}\text { 26. Does not feel disappointed if others disapprove of his/her ideas or } \\
\text { suggestions. }\end{array}$ & .17 & .17 & .22 & .65 & .11 \\
\hline $\begin{array}{l}27 . \text { Is the kind of person who is willing to face any difficulty with the } \\
\text { organization. }\end{array}$ & .33 & .27 & .11 & .64 & .26 \\
\hline 28. Attend and participates in formal and informal hotel meetings. & .21 & .23 & .10 & .14 & .82 \\
\hline 29. Attends functions that are not required, but help the hotel's image. & .26 & .07 & .10 & .17 & .82 \\
\hline 30. 'Keep up' with developments in the hotel. & .43 & .30 & .14 & .24 & .53 \\
\hline
\end{tabular}

F1 = Helping behavior; F2 = Sportsmanship; F3 = Conscientiousness; F4 = Patience and F5 = Civic virtue. 
Table 2. Summary of factor statistics for superior ratings of OCB

\begin{tabular}{|c|c|c|}
\hline Factor & Eigenvalues & Percentage of Variance Explained \\
\hline 1 & 13.19 & 43.98 \\
\hline 2 & 1.85 & 6.16 \\
\hline 3 & 1.61 & 5.35 \\
\hline 4 & 1.27 & 4.22 \\
\hline 5 & 1.03 & 3.43 \\
\hline
\end{tabular}


Table 3. Summary of factor analysis for self-ratings of OCB items

\begin{tabular}{|c|c|c|c|c|c|c|}
\hline \multirow[b]{2}{*}{ Organizational Citizenship Behavior Items } & \multicolumn{6}{|c|}{ Component } \\
\hline & F1 & F2 & F3 & F4 & F5 & F6 \\
\hline $\begin{array}{l}\text { 1. I inform my supervisor before taking any important } \\
\text { actions. }\end{array}$ & .78 & .12 & .10 & .20 & .05 & .08 \\
\hline $\begin{array}{l}\text { 2. I am always willing to cooperate with others to get a job } \\
\text { done. }\end{array}$ & .77 & .20 & .06 & .01 & .12 & .24 \\
\hline 3. I take steps to prevent problems with other workers. & .75 & .17 & .05 & .17 & .13 & .15 \\
\hline 4. I do not abuse the rights of others. & .65 & .19 & .18 & .22 & .04 & .02 \\
\hline $\begin{array}{l}\text { 5. I am concerned with the effects of my actions or } \\
\text { decisions on others. }\end{array}$ & .62 & .07 & .20 & .07 & .25 & -.04 \\
\hline $\begin{array}{l}\text { 6. I obey hotel rules, regulations and procedures even when } \\
\text { no one is watching. }\end{array}$ & .57 & .13 & .26 & .34 & .20 & .18 \\
\hline 7. I pay attention to hotel memos or announcements. & .56 & .31 & .19 & .19 & .22 & .12 \\
\hline 8. I help others who have been absent. & .03 & .82 & .06 & .12 & .05 & -.03 \\
\hline $\begin{array}{l}\text { 9. I willingly give my time to help others with work-related } \\
\text { problems. }\end{array}$ & .20 & .77 & .07 & .10 & .19 & .09 \\
\hline 10. I help others who have heavy work loads. & .30 & .75 & .10 & .08 & -.01 & .09 \\
\hline 11. I help others with demanding work assignment. & .30 & .63 & -.03 & .05 & .25 & .05 \\
\hline $\begin{array}{l}\text { 12. I always leave my work place early without any good } \\
\text { reasons ( R ). }\end{array}$ & .23 & .01 & .71 & .19 & -.06 & .10 \\
\hline $\begin{array}{l}\text { 13. I put in less effort than other members of the work } \\
\text { group }(\mathrm{R}) \text {. }\end{array}$ & .16 & .10 & .71 & .11 & .06 & .15 \\
\hline $\begin{array}{l}\text { 14. I seldom provide constructive ideas or suggestions for } \\
\text { the benefit of the } \\
\text { hotel( R ). }\end{array}$ & -.03 & .13 & .63 & -.07 & .21 & .17 \\
\hline $\begin{array}{l}\text { 15. I seldom give advance notice when unable to come to } \\
\text { work }(\mathrm{R}) \text {. }\end{array}$ & .19 & -.03 & .62 & .06 & -.00 & .17 \\
\hline 16. I never take long lunches. & .20 & .12 & .05 & .85 & .17 & .10 \\
\hline 17. I do not take extra breaks. & .25 & .07 & .10 & .83 & .15 & .10 \\
\hline 18. I am always punctual at work. & .31 & .25 & .21 & .52 & .07 & .17 \\
\hline $\begin{array}{l}\text { 19. I attend functions that are not required, but that help the } \\
\text { hotel image. }\end{array}$ & .15 & .07 & .04 & .11 & .82 & .06 \\
\hline $\begin{array}{l}\text { 20. I attend and participate in formal and informal hotel } \\
\text { meetings. }\end{array}$ & .12 & .23 & .11 & .07 & .70 & .04 \\
\hline 21. I keep abreast of changes in the hotel. & .33 & .09 & .02 & .23 & .62 & .16 \\
\hline 22. I always find faults with what the hotel is doing( $\mathrm{R})$. & .15 & .09 & .13 & .14 & .06 & .78 \\
\hline 23. I tend to make a "mountain out of molehills". & .21 & .09 & .24 & .04 & -.01 & .77 \\
\hline $\begin{array}{l}\text { 24. I consume a lot of time complaining about trivial } \\
\text { matters }(\mathrm{R}) \text {. }\end{array}$ & .03 & -.02 & .23 & .10 & .19 & .66 \\
\hline
\end{tabular}

F1 = Courtesy; F2 = Altruism; F3 = Effort expended; F4 = Conscientiousness; F5 = Civic virtue and F6 = Sportsmanship 
Table 4. Summary of factor statistics for self-ratings of OCB

\begin{tabular}{|c|c|c|}
\hline Factor & Eigenvalues & Percentage of Variance Explained \\
\hline 1 & 7.59 & 31.63 \\
\hline 2 & 2.11 & 8.77 \\
\hline 3 & 1.54 & 6.43 \\
\hline 4 & 1.38 & 5.73 \\
\hline 5 & 1.17 & 4.89 \\
\hline 6 & 1.06 & 4.42 \\
\hline
\end{tabular}

